Linguistic Survey of India. Vol. VIII, Part II : Specimens of the Dardic or Piśacha Languages. By Sir George Grierson, K.C.I.E., D.Litt. pp. vii, 567.

The study of this volume carries us back in thought to that prehistoric time when the ancestors of the Indo-European family lived together in the Steppes, we may suppose, of Eastern Russia, for the very name of these languages raises in our minds the question of the early Aryans and their distribution. The author in a few pages of delightful introduction sketches for us the history of their migrations so far as India and the neighbouring countries are concerned. Through thousands of years we travel back, history is lost in legend, and legend in the mists of conjecture, but we see as in a dream the earliest separation, when some went west to become the forefathers of those who speak the European languages of that sturdy stock; others journeyed east till they halted in the oasis of Khiva. The latter may be called Aryans, but not Indo-Aryans. These Aryans travelled on to the highlands of Khokhand and Badakhshan, and there occurred the second great separation. The parents of the Indo-Aryans went first and their descendants now speak eighteen languages spread over the larger part of India and part of Ceylon. To keep before us the connexions of the three Aryan branches we may retain the word Aryan and call the other two branches Irano-Aryans and PiśācoAryans. To the former belong the Ghalca languages and Persian, Pashto and Biloci; to the latter the Dard languages Șina, Kaśmīin, and Kohistāni. There are nearly forty languages in the Aryan subfamily, and it is interesting to note that the following are taught in the School of Oriental Studies: Irano-Aryan--Persian; Piśaco-AryanȘiṇā and Kaśmīrī ; Indọ-Aryan-Panjabi, Urdu, Hindi, Nepali, Gujrati, Marathi, Bengali, Assamese, Singhalese.

The present volume deals with the Piśāca languages and with Burushaski, which, like Basque in Euroje, cannot be assigned to any known family (cf., however, the article by Edmonston Scott in the fourth number of the BULLETIN, in which a connexion is traced between Muṇ̦ā and Basque). Burushaski is here treated of for two reasons; firstly, because it is geographically convenient to introduce it in this part of the Survey; and secondly, because a substratum of Burushaski works is found in all Piśācã languages, suggesting that it was the original tongue of the country and has been gradually ousted.

Sir George Grierson's work has a double interest for all connected with the Oriental School. There is the interest shared by other students 
of language, which arises out of his great erudition, but there is a further interest due to his having always been a good friend to the School and aided it by personal counsel and effort.

Nearly half of the volume before us is devoted to Kaśminin. Here the author is at his best. The language possesses a literature, the only one of the Piśaco-Aryan group which does; it has competent native scholars who take a pride in it and understand it; and finally, Sir George has studied it for many years and is the chief European authority upon it. He has published several works dealing with it. If, therefore, there were no specimens to illustrate it, no texts or translations, it would make no difference to the accuracy or fulness of the treatment which it would receive at his hands. There is an admirable discussion of the linguistic relationship of Kaśmīī, in which it is shown that the language, however much it may now be overlaid with Sanskritic words, really belongs to the Pišācā group. This is followed by an illuminating treatise on Kaśmīrī grammar.

The author is led into one mistake through having derived his knowledge from Pandits. More than once he states that Kaśmīī contains no cerebral ??. It is true that many city dwellers, especially Pandits, do not pronounce the letter, but the great majority of the people use it regularly. Of the many Kaśmiris with whom I have conversed over 90 per cent employed cerebral $r$. Moreover, the use is not occasional or haphazard; it is regular and constant. Thus the common words ś $u r^{u}=$ boy, kiu $?^{\cdot i t}=$ girl, $g u r^{u}=$ horse, and many others contain cerebral ? ; similarly the usual ending ? found in words meaning "whither, hither, thither", etc., is cerebral. Of course, perfect consistency is not human, but the use of cerebral letters is as regular as in Indo-Aryan languages. The whole question of apparent inconsistencies or irregularities in pronunciation, whether of cerebral or other letters, requires investigation, but it can be undertaken only among the people themselves and by those whose ears can unhesitatingly catch the necessary distinctions. The subject is one of much interest.

Over 80 pages are devoted to that fascinating language Șinā. Here, and in the remaining languages of the volume, the available materials are inadequate, and it is not possible to speak with such certainty. It is wonderful how full is the grammatical information which the author has been able to deduce. In the circumstances pronunciation must be largely a matter of guesswork, for none of the specimens have been prepared by native speakers of the language or by anyone born 
in the country in which these speakers live. One specimen of Șinā was prepared by an Indian, and it is noteworthy that the cerebrals which occur in his own language are given with absolute accuracy, while those which were foreign to him are ignored. Sir George Grierson comes to the natural conclusion that as the specimens vary much in the use of cerebrals there may be no cerebrals such as we are accustomed to in India. This is, however, not borne out by facts. As the matter is one of importance I give a brief statement, the result of minute observations among speakers of five dialects of Șināa, viz. those spoken in Kohistān, Cilās, Gilgit, Gurēs, and Drās.

Sinnā has no less than nine cerebral letters ; in addition to $t, d, n$, $l, ?$, found in North India, there are $s, z, c$, and cerebral $j$. Of these $t$ and $c$ may be aspirated. The $t r$ and $j r$ which appear in one of the specimens are attempts to render $c$ and cerebral $j$. The cerebrals and aspirates in Sinã are used with great consistency throughout the whole area over which the language is spoken. How remarkable this is we realize when we remember that Drās is about twenty marches away from Kohistān. The cerebrals $t, d, l, n, r$ are pronounced practically as in India, and it is an important fact that the majority of the words containing them are non-Sanskritic, which goes to prove that the original Aryan language had cerebrals. $l$ is found only in Dräsī, or accidentally in Gurēsī.

The beginning of the book is given to the Käfir languages and Citrālī, and the end to Kohistānī and Burushaski. These languàges are treated with much lucidity, and once again we wonder at the author's extraordinary grasp of facts and the ability to marshal them in logical sequence. When we abuse our benign Government we must in fairness to them recall the happy inspiration which induced them to entrust the linguistic survey to a scholar of the calibre of Sir George Grierson.

T. Grahame Bailey.

\section{TOD'S RAJASTHAN}

Annals and Antiquities of Rajasthan, or the Central and Western Rajput States of India. By Lieut.-Col. James Tod, late Political Agent to the Western Rajput States. Edited, with an introduction and notes, by William Crooke, C.I.E., Hon. D.Sc. Oxon. (late of the Indian Civil Service). 3 vols. Oxford University Press. 52s. 6d. net.

Tod's classical work was first published in two volumes between the years 1829 and 1832, and was reprinted at Madras in 1873, at 